\title{
POMC wt Allele
}

National Cancer Institute

\section{Source}

National Cancer Institute. POMC wt Allele. NCI Thesaurus. Code C52424.

Human POMC wild-type allele is located in the vicinity of 2 p23.3 and is approximately $8 \mathrm{~kb}$ in length. This allele, which encodes pro-opiomelanocortin protein, plays a role in the modulation of steroid production, pain response, energy homeostasis, melanin production and immune responses. Mutations in this gene have been associated with early onset obesity, adrenal insufficiency, and red hair pigmentation. 